\title{
The influence of dietary protein and fibre on bile-pancreatic secretion in sheep
}

\section{T. Żebrowska, J. Kowalczyk, J. J. Pająk and Z. Dlugolęcka}

\author{
The Kielanowski Institute of Animal Physiology and Nutrition, \\ Polish Academy of Sciences \\ 05-110 Jablonna, Poland
}

(Received 22 August 2001; accepted 6 November 2001)

\begin{abstract}
Two experiments, each on 6 sheep of about $40 \mathrm{~kg}$ liveweight, fitted with a catheter in the common bile duct and a T-piece cannula in the duodenum, were conducted to assess the influence of fibre (Experiment 1) and protein (Experiment 2) in the dict on exocrine pancreatic and bile secretion. Three isonitrogenous dicts made of meadow hay and concentrate containing 134 (LF), 200 (MF) or 313 (HF) g/kg crude fibre (Experiment !) and threc dicts containing similar levels of tibre and 130 (LP), 170 (MP) and 200 (IIP) g/kg crude protein (Experiment 2) were fed. Mean volumes of bilepancreatic juice and total nitrogen content were not affected by the level of fibrc and amounted to $1294 \mathrm{ml}$ and $3.11 \mathrm{~g} / 24 \mathrm{~h}$, respectively. Mean volumes of secretions were higher $(\mathrm{P}<0.01)$ on the $\mathrm{HP}$ than on the LP and MP diets. Total nitrogen was higher $(\mathrm{P}<0.05)$ on $\mathrm{HP}(3.35 \mathrm{~g} / 24 \mathrm{~h})$ than on $\mathrm{LP}$ and MP $(2.66 \mathrm{~g} / 24 \mathrm{~h})$. Total activity $(\mathrm{U} / 24 \mathrm{~h})$ of trypsin and chymotrypsin were nol affected by the fibre level in the diet. Total activity of trypsin on the LP, MP, and HP diets was similar but chymotrypsin activity was greater $(\mathrm{P}<0.01)$ on the HP than on the LP and MP diets. The amino acid composition of bile-pancreatic secretions was not affected by the diet composition.
\end{abstract}

KEY WORDS: shecp, diet, protein, fibre, bile-pancreatic secretion

\section{INTRODUCTION}

Numerous studies have been conducted in different species to clucidate the physiological characteristics of exogenous pancreatic secretion. Activities of digestive enzymes produced by the pancreas are influenced by diet composition and are adapted to obtain effective digestive processes (Harada and Takeuchi, 1999). 
In some non-ruminants high protein diets significantly increase the activity of pancreatic chymotrypsin and trypsin (Brannon, 1990) while in pigs, a high protein diet increases secretion of chymotrypsin, but trypsin secretion remains relatively constant (Corring, 1977).

Adaptation of pancreatic protein and proteolytic enzyme secretion to dietary composition in ruminants has been investigated less than in other species. Experiments similar to studies on monogastrics showing increased proteolytic enzyme secretion with increased protein intake are lacking for ruminants (Croom et al., 1992; Harmon, 1993). In ruminants with fully developed forestomachs, the composition of digesta entering the duodenum is less influenced by diet composition than in monogastrics. Ruminal fermentation is why microbial protein is the predominant source of protein entering the duodenum under most feeding conditions and its proportion in total protein of the digesta does not change very much. On the other hand, adaptation of pancreatic proteases responds only to the amount and composition of intestinal digesta protein (Brannon, 1990).

It was shown by Harada and Takeuchi (1999) that short chain fatty acids, which are the major end products of microbial fermentation of carbohydrates in the rumen, stimulate pancreatic enzyme secretion. This may suggest that different proportions of fibre or starch in the diet could result in a different output of enzymes in pancreatic juice.

The aim of the present study was to examine the influence of the level of fibre and poorly degradable zcin protein in the diet on the volume of pancreatic and bile secretion, and the content of nitrogen on trypsin and chymotrypsin activity.

\section{MATERIAL AND METHODS}

Two experiments, each on 6 Polish Merino male sheep of about $40 \mathrm{~kg}$ liveweight, were conducted in a $2 \times 2$ Latin square design. The animals were fitted with a silastic catheter into the common bile duct and a cannula into the duodenum distal to the papillae. In Experiment 1 the animals were fed isonitrogenous diets with low (LF), medium (MF) or high (HF) fibre contents (Table 1), and in Experiment 2 the sheep were given diets with low (LP), medium (MP) or high (HP) protcin contents and a similar proportion of fibre (Table 2). Diets containing contrasted levels of fibre were prepared by including different amounts of meadow hay, and those with contrasting levels of protein were made by including different amounts of zein. The animals received $1 \mathrm{~kg}$ of feed per day in four equal portions given every $6 \mathrm{~h}$ (Experiment 1 ) and two equal portions given every $12 \mathrm{~h}$ (Experiment 2), with free access to water.

After 12 days of adaptation to the tested diets the bile-pancreatic juice was collected continuously for $48 \mathrm{~h}$ into bottles kept on ice. The weight of the juice 
was measured every hour and 5\% samples were taken and pooled for $6 \mathrm{~h}$ in Experiment 1 and for $12 \mathrm{~h}$ in Experiment 2. The remaining secretion was returned to the duodenum by means of a peristaltic pump at a rate similar to the outflow. Samples taken for analysis were stored at $-70^{\circ} \mathrm{C}$ until analysis.

TABLE 1

Composition of the diets, $\mathrm{g} / \mathrm{kg}$

\begin{tabular}{|c|c|c|c|}
\hline & \multicolumn{3}{|c|}{ Diets } \\
\hline & \multicolumn{3}{|c|}{ Experiment I } \\
\hline & $\mathrm{LF}^{\prime}$ & $\mathrm{MF}^{2}$ & $\mathrm{HF}^{3}$ \\
\hline Meadow hay & 400 & 700 & 950 \\
\hline Ground barley & 495 & 200 & - \\
\hline Soyabean meal & 105 & 100 & 50 \\
\hline Crude protein, $\mathrm{g} / \mathrm{kg}$ & 151 & 158 & 160 \\
\hline \multirow[t]{3}{*}{ Crudc fibre, $\mathrm{g} / \mathrm{kg}$} & 134 & 200 & 315 \\
\hline & \multicolumn{3}{|c|}{ Experiment 2} \\
\hline & L. $P^{4}$ & $M P^{s}$ & $\mathrm{HP}^{6}$ \\
\hline Meadow hay & 600 & 600 & 600 \\
\hline Ground barley & 400 & 400 & 400 \\
\hline Zein & - & 40 & 90 \\
\hline Crude protein, $\mathrm{g} / \mathrm{kg}$ & 130 & 170 & 200 \\
\hline Crude fibre, $\mathrm{g} / \mathrm{kg}$ & 205 & 197 & 188 \\
\hline
\end{tabular}

'- low fibre level; ${ }^{2}$ - medium fibre level; ${ }^{3}$ - high fibre level

${ }^{4}$ - low protein level; ${ }^{5}$ - medium protein level; ${ }^{6}$ - high protcin ievel

TABLE 2

Mean volume of bile-pancreatic juice and amount of total nitrogen secreted during $24 \mathrm{~h}$

\begin{tabular}{lccc}
\hline Diets & $\begin{array}{c}\text { Bile-pancreatic juice } \\
\mathrm{ml}\end{array}$ & $\begin{array}{c}\text { Total nitrogen } \\
\mathrm{g}\end{array}$ & $\begin{array}{c}\text { Total nitrogen } \\
\% \text { of intake }\end{array}$ \\
\hline $\mathrm{LF}^{3}$ & 1337 & $\begin{array}{c}\text { Experiment } 1 \\
3.27\end{array}$ & 13.6 \\
$\mathrm{MF}^{2}$ & 1324 & 3.09 & 12.9 \\
$\mathrm{HF}^{3}$ & 1222 & 2.97 & 12.4 \\
& & & \\
$\mathrm{LP}^{4}$ & $1160^{\mathrm{B}}$ & Experiment 2 & 14.5 \\
$\mathrm{MP}^{5}$ & $1292^{\mathrm{AB}}$ & $2.65^{\mathrm{a}}$ & 11.5 \\
$\mathrm{HP}^{6}$ & $1398^{\mathrm{A}}$ & $2.68^{\mathrm{a}}$ & 11.3 \\
\hline
\end{tabular}

AB $\mathrm{P}<0.01$; ab $\mathrm{P}<0.05$

1.2.3.4,5.6. - as in Table 1 
Total nitrogen and crude fibre in feeds and total nitrogen in bile-pancreatic juice were analysed using standard methods (AOAC, 1990). Amino acid analysis of juice was performed with a Beckman 6300 High Pressure Amino Acid Analyzer using modified procedures according to Buraczewska and Buraczewski (1981). Trypsin and chymotrypsin activities were estimated according to the method described by Hummell (1959).

The results were subjected to one-way analysis of variance using Statgraphics Plus ver. 7.0 (1993).

\section{RESULTS}

In Experiment 1 the volumes of bile-pancreatic juice were similar during four consecutive $6 \mathrm{~h}$ periods and amounted to 331,334 and $303 \mathrm{ml}$ for diets LF, MF and $\mathrm{HF}$, respectively. The mean bile-pancreatic juice output in $24 \mathrm{~h}$ did not differ significantly among diets LF, MF and HF (Experiment 1) but was significantly higher $(\mathrm{P}<0.01)$ after feeding the MP and HP diets than LP (Experiment 2; Table 2).

The mean content of total nitrogen was not significantly affected by the level of fibre and amounted to $3.11 \mathrm{~g} \mathrm{~N} / 24 \mathrm{~h}$ (Experiment 1), but in Experiment 2 the total nitrogen content was significantly greater $(\mathrm{P}<0.05)$ with diet $\mathrm{HP}(3.35 \mathrm{~g} / 24 \mathrm{~h})$ than with diets LP and MP (2.65 and $2.68 \mathrm{~g} / 24 \mathrm{~h}$ ) (Table 2).

The total activity (U/24 h) of trypsin and chymotrypsin in bile-pancreatic juice was not affected by the level of fibre in the diet. The total activity of trypsin on diets LP, MP and HP was similar but chymotrypsin activity was greater $(\mathrm{P}<0.01)$ on diet HP than on LP and MP (Table 3).

The amino acid composition of bile-pancreatic juice, expressed in $\mathrm{g} / 16 \mathrm{~g} \mathrm{~N}$, was similar after feeding the animals all of the experimental diets (Table 4).

TABLE 3 Total enzymatic activity (U) of trypsin and chymotrypsin in the bile-pancreatic juice secreted in $24 \mathrm{~h}$

\begin{tabular}{llll}
\hline Diets & Trypsin & Chymotrypsin \\
\hline LF $^{1}$ & & Experiment l & \\
MF $^{2}$ & 66221 & & 37804 \\
$\mathrm{HF}^{3}$ & 59388 & 37482 \\
& 69204 & 39750 \\
LP $^{4}$ & & & \\
MP $^{s}$ & 52011 & & $29082^{\text {Aa }}$ \\
HP $^{6}$ & 58548 & $34357^{\text {Abc }}$ \\
\hline
\end{tabular}

1,2.3.1.5.6 - as in Table 1 
TABLE 4

Mean amino acid content in bile-pancreatic juice secreted in $24 \mathrm{~h}, \mathrm{~g} / 16 \mathrm{~g} \mathrm{~N}$

\begin{tabular}{|c|c|c|}
\hline Amino acid & Experiment $]$ & Experiment 2 \\
\hline & \multicolumn{2}{|c|}{ Essential amino acids } \\
\hline Threonine & 4.8 & 4.9 \\
\hline Valine & 5.8 & 6.1 \\
\hline lsoleucine & 4.0 & 4.0 \\
\hline Lcucine & 6.3 & 6.4 \\
\hline Tyrosine & 4.7 & 4.8 \\
\hline Phenylalanine & 3.1 & 3.2 \\
\hline Histidine & 1.8 & 1.8 \\
\hline Lysine & 4.6 & 4.8 \\
\hline \multirow[t]{2}{*}{ Methionine } & 0.8 & 0.9 \\
\hline & \multicolumn{2}{|c|}{ Non-essential amino acid } \\
\hline Asparagine & 9.5 & 9.7 \\
\hline Serine & 6.1 & 6.7 \\
\hline Glutamine & 7.8 & 8.3 \\
\hline Proline & 3.4 & 3.5 \\
\hline Glycine & 9.7 & 7.7 \\
\hline Alanine & 4.4 & 4.5 \\
\hline Arginine & 3.1 & 3.3 \\
\hline \multirow[t]{3}{*}{ Cysteine } & 3.3 & 3.2 \\
\hline & \multicolumn{2}{|c|}{ Total amino acid } \\
\hline & 83.2 & 83.8 \\
\hline
\end{tabular}

\section{DISCUSSION}

Pancreatic and bile secretion in ruminants may differ from that of monogastrics because of ruminal fermentation of fibre-rich diets, absorption of the end products and continuous postruminal flow of digesta. The digestive condition of ruminants differs considerably therefore from the posprandial, postabsorptive conditions of monogastrics. Taylor (1962) and Pierzynowski (1986) reported that pancreatic juice secretion in sheep fed standard diets is continuous with no or small changes after feeding, however, in cattle kept without feed for $48 \mathrm{~h}$ the volume of juice declined to about 50\% (Pierzynowski, 1989).

According to Harada and Kato (1983), volatile fatty acids (VFA), which in ruminants are the main end product of carbohydrate microbial fermentation in the rumen, are potential stimulators of pancreatic exocrine secretion. They showed that butyrate, propionate and acetate given intravenously stimulated pancreatic juice flow, protein and amylase secretion under anaesthesia conditions. 
In our study we did not find any effect of the diets containing different proportions of meadow hay and barley grain and therefore different amounts of fibre and starch on bile-pancreatic juice output, total nitrogen content and total trypsin and chymotrypsin activity. It is possible that under such dictary conditions, microbial fermentation, the rate of absorption and the proportion between particular VFAs absorbed did not differ enough to affect pancreatic secretion. In the presented experiment pancreatic juice and bile were collected together and the greater volume of bile than of pancreatic juice could mask small changes in pancreatic juice volume. On the other hand, similar values of trypsin and chymotrypsin activities for all three experimental diets suggest that under our experimental conditions differences in fibre content in the diets had no or only a small effect on secretion of pancreatic proteases.

Increasing the protein content in the diet from 130 to $200 \mathrm{~g} / \mathrm{kg}$ by addition of zein significantly enhanced the amount of bile-pancreatic juice and total nitrogen sccretions during $24 \mathrm{~h}$, while increasing the protein content to $170 \mathrm{~g} / \mathrm{kg}$ of the diet had no effect. Trypsin activity did not change with increasing protein content but chymotrypsin activity was significantly higher when protein was supplemented than on the control diet. Studies on pigs (Corring, 1977) and rats (Brannon, 1990) showed that pancreatic secretions and trypsin and chymotrypsin activities increased as the protein content in the diets rose, and chymotrypsin showed a more sensitive response to changes in protein consumption.

Nitrogen compounds entering the digestive tract with bile-pancreatic juice may play a significant role in the total nitrogen recycling system in sheep, which supports the results reported by Krawielitzki et al. (1999) who, using the ${ }^{15} \mathrm{~N}$ dilution method in sheep, estimated that more than $9 \mathrm{~g} \mathrm{~N} / \mathrm{d}$ of endogenous nitrogen was secreted into the stomachs and proximal duodenum, including pancreatic juice and bile. In the present study the amount of total $\mathrm{N}$ secreted in pancreatic juice and bile daily ranged from 2.65 to $3.35 \mathrm{~g}$, which accounted for about $28 \%$ of that secreted into that part of the digestive tract, and from 11.3 to $13.6 \%$ of daily nitrogen intake.

\section{CONCLUSIONS}

The fibre content in the diet for sheep has no influence on bile-pancreatic juice secretion or its amino acid profile, but a higher undegraded protein level in the diet increases nitrogen secretion and chymotrypsin activity in sheep. 


\section{REFERENCES}

AOAC, 1990. Official Methods of Analysis. Association of Official Analytical Chemists. $15^{\text {th }}$ Edition. Arlington, VA

Brannon P.M., 1990. Adaptation of the exocrine pancreas to diet. Ann. Rev. Nutr. 10, 85-105

Buraczewska L., Buraczewski S., 1981. A note on determination of methionine and tryptophane. Procecdings of $6^{\text {th }}$ International Symposium on Amino Acids, Serock (Poland), pp. 47-50

Corring T., 1977. Possible role of hydrolysis products of the dietary components in the mechanisms of the exocrine pancreatic adaptation to the diet. World Rev. Nutr. Diet. 27, 132-137

Croom W.J. Jr., Bull L.S., Taylor I.L., 1992. Regulation of pancreatic exorine secretion in ruminants: A review. J. Nutr. 122, 191-202

Harada E., Kato S., 1983. Effect of short-chain fatty acids on the secretory response of the ovine exocrine pancreas. Amer. J. Physiol. 244, G284-G289

Harada E., Takeuchi T., 1999. Characteristics of pancreatic exocrine secretion in herbivores. In: S.G. Pierzynowski, R. Zabielski (Editors). Biology of the Pancreas in Growing Animals. Elsevier, Amsterdam, pp. 423-436

Harmon D.L., 1992. Impact of nutrition on pancreatic exocrine and endocrine secretion in ruminants: A review. J. Anim. Sci. 70, 1290-1301

Harmon D.L., 1993. Nutritional regulation of postruminal digestive enzymes in ruminants. J. Dairy Sci. 76, 2102-2111

Hummell B.C.W., 1959. A modified spectrophotometric determination of chymotrypsin, trypsin and thrombin. Can. J. Biochem. Physiol. 37,1393-1399

Krawielitzki K., Sandek A., Kowalczyk J., Kreinbring F., Żebrowska T., Skiba B., Voigt J., Gabel M., Hagemeister H., 1999. Nitrogen secretion and absorption in different scgments of the digestive tract estimated by digesta exchange between ${ }^{15} \mathrm{~N}$-labelled and unlabelled sheep. J. Anim. Feed Sci. 8, 129-143

Picrzynowski S.G., 1986. The secretion of pancreatic juice in sheep in different feed treatments. Pol. Arch. wet. 26, 31-39

Pierzynowski S.G., 1989. The effect of fasting and subsequent lon-term intraduodenal glucose infusion on the exocrine pancreas sccretion in catlle. J. Anim. Physiol. Anim. Nutr. 63, 198-203

Statgraphics ${ }^{*}$ Plus ver. 7, 1993. Statistical Graphics System by Graphic Corporation

Taylor R.B., 1962. Pancreatic secretion in sheep. Res. Vet. Sci. 3, 63-67

\section{STRESZCZENIE}

\section{Wplyw poziomu bialka i wlókna w diecie na sekrecję żólciowo-trzustkową u owicc}

Przcprowadzono dwa doświadczenia, każde na 6 trykach o masie ciała około $40 \mathrm{~kg} \mathrm{z}$ kateterami umieszczonymi w przewodzie wspólnym żółciowo-trzustkowym i prostą kaniulą w dwunastnicy. Zwierzçta żywiono w układzic kwadratu łacińskiego: w doświadczeniu 1-dietami składającymi się z siana łąkowego i mieszanki treściwej, zawierającymi 134 (LF), 200 (MF) i 313 (HF) g/kg włókna surowego, a w doświadczeniu 2 - dietami zawierającymi 130 (LP), 170 (MP) i 200 (HP) g/kg białka ogólnego przy zbliżonej zawartości włókna. Objętość soku trzustkowego z żólcią i zawartość w nim azotu ogólnego nie zależala od poziomu włókna w dawce i wynosiła średnio $1294 \mathrm{ml}$ 
i 3,11 g/dobę, odpowiednio. Przy żywieniu dietą HP objętość soku była większa $(\mathrm{P}<0,01)$ niż przy skarmianiu diet MP i LP, a ilość wydzielonego azotu przy diecie HP wynosiła $3,35 \mathrm{~g} /$ dobę i była większa $(\mathrm{P}<0,05)$ niż przy skarmianiu diet LP i MP $(2,66 \mathrm{~g} /$ dobę $)$. Ogólna aktywność trypsyny i chymotrypsyny nie zależała od poziomu włókna w dawce. Poziom białka w dawce nie wpłynął na aktywność trypsyny, natomiast aktywność chymotrypsyny była większa $(\mathrm{P}<0,01)$ przy żywieniu dietą HP niż LP i MP. Skład aminokwasowy soku trzustkowego z żółcią był zbliżony przy skarmianiu wszystkich diet. 